\title{
SURVIVING AND QUITTING: THE CASE OF 4PS (PANTAWID PAMILYANG PILIPINO PROGRAM) STUDENT DROPOUTS
}

\author{
Lyra Paz P. Lluz *1ه \\ ${ }^{* 1}$ University of Eastern Philippines-Pedro Rebadulla Memorial Campus and University Research \\ and Development Services, University of Eastern Philippines, Catarman, Northern Samar 6400, \\ Philippines
}

DOI: https://doi.org/10.29121/granthaalayah.v8.i8.2020.971

Article Type: Research Article

Article Citation: Lyra Paz P. Lluz. (2020). SURVIVING AND QUITTING: THE CASE OF 4PS (PANTAWID PAMILYANG PILIPINO PROGRAM) STUDENT DROPOUTS. International Journal of Research GRANTHAALAYAH, 8(8), 297-301. https://doi.org/10.29121/granthaa layah.v8.i8.2020.971

Received Date: 03 August 2020

Accepted Date: 31 August 2020

Keywords:

Pantawid Pamilyang Pilipino

Program (4ps)

Dropout

Student

Poverty

\section{ABSTRACT}

The Pantawid Pamilyang Pilipino Program (4Ps) is a version of cash transfer program here in the Philippines that aims to eradicate extreme poverty by investing in health and education. This study focused on personal experiences of students as 4Ps beneficiaries and factors that have led to their dropping out from school. A qualitative method was employed utilizing a case study design, where data was gathered from six (6) student dropouts who were 4Ps beneficiaries. Results revealed that most student beneficiaries of the 4Ps are from indigent families, highlighted that factors were due to family living conditions, the desire to help the parents and siblings. Family living conditions, the poor standard of living still is a pressing problem that can led students to drop out from school, even with the availability of financial assistance that still links to poverty as an underlying factor.

\section{INTRODUCTION}

Poverty has been one of the major problems and societal concerns in the country. Among various indicators of poverty, Filipinos were found to be most deprived in gaining access to education, the new multidimensional poverty index (MPI) created by the Philippine Statistics Authority (PSA) showed. Poverty is a condition in which people lack the basic things in order to survive such as food, shelter, water, clothes and education (Crossman, 2014).

Dela Torre (2016) noted that most of the problems and difficulties of Filipinos are rooted in poverty. Many families are left deprived of their basic needs and therefore forced their children to stop going to school and help them instead in their livelihood. With this main ground, the Philippine government initiated a program called the Pantawid Pamilyang Pilipino Program or 4P's both to address poverty and in response to the country's commitment to the Millennium Development Goals (MDGs).

The Pantawid Pamilyang Pilipino Program (4Ps) is a human development measure of the national government that provides conditional cash grants to the poorest of the poor, to improve the health, nutrition, and the education of children aged 0-18. It is patterned after the conditional cash transfer (CCT) schemes in Latin American and African countries, which have lifted millions of people around the world from poverty. 4Ps is a version of cash transfer

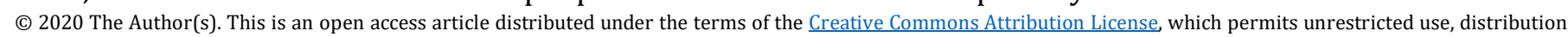
and reproduction in any medium, provided the original author and source are credited. 
Surviving and Quitting: The Case of 4ps (Pantawid Pamilyang Pilipino Program) Student Dropouts

program here in the Philippines under the Department of Social Welfare and Development, its aim is to eradicate extreme poverty in the Philippines by investing in health and education particularly to children from 0-18 years old (Montilla, et.al, 2015).

Children of the 4Ps beneficiaries are referred to Commission on Higher Education (CHED) which is also DSWD's partner in the project along with the Department of Labor and Employment (DOLE) and the implementing state universities and colleges (SUCs). Under the said program, it ensures that the grantees are enrolled in selected SUCs duly recognized by CHED, channeled to CHED priority courses, and be extended the needed support that will guarantee completion of studies, thus qualify them for high-value added jobs in the future. (Junio, 2014). In partnership with the Commission on Higher Education, the Department of Labor and Employment, and the Philippine Association of State Universities and Colleges, 4Ps has enrolled 36,003 beneficiaries in state universities and colleges as of June 2015 (officialgazette.gov.ph). The program has strict compliance when it comes to the school attendance of the students who are beneficiaries because it is their basis in giving the cash transfer. It is therefore expected for the beneficiaries to attend school regularly or at least $85 \%$ of the school days. There are studies that shows how the 4Ps program affects the school attendance and the performance of the student.

Northern Samar as one of the poorest provinces in the country is a beneficiary of Pantawid Pamilyang Pilipino Program (4Ps) covering 44,928 households, out of which 79,607 are children beneficiaries for educational grants in all school levels in 24 municipalities (Diaz, 2018). Most college student 4Ps beneficiaries are enrolled in the University of Eastern Philippines campuses. About $50 \%$ of the student population are 4Ps grantees, receiving monthly stipend and necessary support for school-related activities and these students were the priority beneficiaries of the Tertiary Education Subsidy (TES). Enrollment was seen to increase with the 4Ps implementation, but while enrollment and school facilities are increasing, some children remain out of school and there are still many cases of drop-outs.

With the cases of students dropping out from school despite the support given, at a closer look, there can be underlying reasons for such. To address this gap, this study aims to explore and describe these underlying factors that have led to their dropping out from school.

\section{METHODOLOGY}

This study is anchored on the pull-out theories of student dropping, which associate the student's decision to leave school with factors such as: early marriage, having a baby, financial issues, the need to get employed in order to support their family. The pull-out theories assume the fact that students underlie the decision to stay in school or not on a cost - benefit analysis [McNEal, 1997; Mihalic \& Elliott, 1997]. These theories consider the individual in a contextual way, in which school is an important part of his life, along with his family, colleagues, church and other organizations. A job or the family responsibilities, for instance, are able to get the student out of school.

On the other hand, this study is also anchored on the push-out theories which consider that the school is to blame for the dropout because it discourages students regarding continuing studies using as argument their personality traits. Internal institutional factors, such as the behavioral policies or the conflicts between students or teachers, may push the students outside the school. The pushout theoreticians claim that the students leave school not due to their individual attributes but because of the school structure [Fine, 1991]. Jordan, Lara and McPartland (1996) define the push effects as school related factors with negative impact upon the bond that teenagers achieve with the school environment and makes them reject the school context. These factors may be structural, contextual, climate related or individualized and may determine some students to consider school as an unwelcoming place [Stearns \& Glennie, 2006].

\subsection{RESEARCH DESIGN}

This study employed a qualitative design which follows a systematic subjective approach to capture relevant data. A case study research will allow the researchers to focus on a specific area or situation for an in-depth analysis (Heigham, et.al., 2009). Case study research is said to allow for in-depth review of new or unclear phenomena while retaining the holistic and meaningful characteristics of real-life events (Hartley, 2004). This design is employed in this study, as this aims to explore and describe personal experiences of students as 4Ps beneficiaries and factors that have led to their dropping out from school. 


\subsection{RESEARCH PROCEDURE}

The researcher employed purposive sampling in order to collect relevant data from the participants. Chosen participants were students who dropped out from school who were 4Ps beneficiaries, selected from the previous semester records. The researcher selected ten (10) student dropouts, but was able to reach only six (6) of them and the researcher also conducted an interview with the six (6) chosen participants who were found in their respective homes and the interview was personally administered by the researcher. First, they were invited to be part of the study and were informed of its nature, their rights and were ensured of the confidentiality of their responses. The participants personally consented to the interview.

\subsection{RESEARCH INSTRUMENT}

An interview guide was utilized in this study. It consisted of preparatory questions which established rapport between the interviewer and the interviewee. The participant was asked of questions about the time they have been in school and their being 4Ps grantees, which further led to questions about factors that cause their dropping out from school.

A transcript was produced from the interview sessions that served as sources of data in coming up with codes and themes that helped the researcher synthesize answers to the research questions.

\subsection{ETHICAL CONSIDERATIONS}

The information that were used in this research were the individual views of participants on the issues related to the subject. Hence, in the interest of future predicaments that may arose based on the impressions of the readers, the identities of the participants were not divulged in this study. The researcher reserved the right to protect the participants and the confidentiality of their responses in general.

\subsection{DATA ANALYSIS}

Data from the interview were transcribed and analyzed through thematic analysis. Thematic analysis is the process of identifying patterns or themes within qualitative data (Braun \& Clarke (2006). The goal of a thematic analysis is to identify themes, i.e. patterns in the data that are important or interesting, and use these themes to address the research or say something about an issue. This is much more than simply summarizing the data; a good thematic analysis interprets and makes sense of it (Clarke \& Braun, 2013).

\section{RESULTS AND DISCUSSION}

Information gathered from the respondents through in-depth interview was processed through its methodology to gather reliable results and validation of the questions in terms of clarity, understandability, and appropriateness (Creswell, 2013). The following presentations are the results and discussions that came out of the analysis.

\section{Theme 1: '4ps helped students in many ways.'}

Participants claimed that the program was a big help to them in their stay in school. "I was so thankful I was chosen that time as a grantee of the financial assistance, more that my parents really can't send me to school" (Nagpasalamat gud ak sadto nga nahiapi ak, kay sugad ko maka iskwela na ak, kay dire man gud kaya san ak mga kaganak), P1 said. "Yes, it was really helpful", P2 added.

Responses of the participants highlighted that the program was beneficial to students. "We receive monthly stipend, although sometimes it does not arrive on time, but it was really a big help" P3 said. "I use the assistance for my school needs, but most of the time, I give it to my parents and they spend it for some of our basic needs, it really helped me a lot as a student and my family as well."

The participants responded mostly positive things about the program. The financial assistance was able to help them with their daily needs in school, pay their school contributions, for their daily fare and school projects. 
Surviving and Quitting: The Case of 4ps (Pantawid Pamilyang Pilipino Program) Student Dropouts

Throughout the interview, it was noted that participants do have positive views of the effects of 4Ps to their education and that they see it helpful.

\section{Theme 2: 'Students need more to sustain interest for schooling.'}

Despite the positive remarks of the participants about the program, their responses eventually led to several factors why despite the financial support given, they quit school and decided not to continue. It may sound unusual why despite the support extended by the government, still students cannot sustain their schooling, when the financial burden has been lifted.

"I dropped because I don't feel going to school at all. Yes, there is 4Ps, but I have to help my parents work for our daily needs. Practically, I have to work," a participant exclaimed. "My parents said I have to go to school, but for me, I find it impractical when I see my younger siblings need my help," another participant said. "I lose interest, just that I felt there is no sense going to school when I can earn working in the field. 4Ps can pay my tuition and school needs, but I eat daily, we have other needs."

Most of the participants were from indigent families, with parents who earn lower than the minimal income. Responses highlighted that the financial assistance really was not enough to motivate them to continue schooling.

\section{Theme 3: 'Staying in school is a choice that may be affected by related factors.'}

'I would like to stay. I would like to finish college, but I need to help my parents." This response clearly distinguishes one's choice of quitting from school than stay. "Our living condition, my parents need me, my younger siblings have to go to school, so I decided to quit school and work. This way I can help them," a participant said.

"It was my choice to drop from school. I have to help my parents," another participant added. Most of the participants mentioned family reasons related to their living conditions as the pressing factor that cause them to drop from school. Related factors like the need to help their parents and their younger siblings were highlighted in their responses.

The pull-out theories of student dropping associates student's decision to leave school with factors such as: early marriage, having a baby, financial issues, and the need to get employed in order to support their family. The pull-out theories assume the fact that students underlie the decision to stay in school or not on a cost - benefit analysis. From the participants, their responses were along this area. Considering that most student beneficiaries of the 4Ps are from indigent families, they still have needs that pressed them to quit from school despite the financial assistance provided.

It was quite clear that factors do not incline to the push-out theory which consider that the school is to blame for the dropout because it discourages students regarding continuing studies using as argument their personality traits. The interview with the six (6) student dropouts highlighted that factors were due to family living conditions, the desire to help the parents and siblings. Despite the fact that there was the financial assistance, participants weighed the benefit of dropping out from school and work to help their parents. In reality, cases like these cannot be avoided especially that there are other needs that seem much more important than staying in school.

Poverty and dropouts are inextricably connected in the three primary settings affecting healthy child and adolescent development: families, schools and communities. In 2009, poor students were five times more likely to drop out of high school than high-income students (Chapman, Laird, Ifill, \& KewalRamani, 2011).

\section{CONCLUSION}

The Pantawid Pamilyang Pilipino Program (4Ps) is beneficial to students, however there are cases that students may find dropping out from school an option better than staying. Surviving school is not an option for students who chose to quit school and find it more practical. Family living conditions, the poor standard of living still is a pressing problem that can led students to drop out from school, even with the availability of financial assistance that still links to poverty as an underlying factor.

\section{SOURCES OF FUNDING}

This research received no specific grant from any funding agency in the public, commercial, or not-for-profit sectors.

International Journal of Research -GRANTHAALAYAH 


\section{CONFLICT OF INTEREST}

The author have declared that no competing interests exist.

\section{ACKNOWLEDGMENT}

None.

\section{REFERENCES}

[1] Chapman, C., Laird, J., Ifill, N., \& Kewal Ramani, A. (2011). Trends in high school dropout and completion rates in the United States: 1972-2009. (NCES 2012-06). Washington, D.C.: National Center for Education Statistics, Institute of Education Sciences, U.S. Department of Education. Retrieved [date]. Source: http://nces.ed.gov/pubsearch/pubsinfo.asp?pubid=2012006

[2] Creswell, J.W. (2013). Qualitative Inquiry \& Research Design: Choosing Among the Five Approaches. Thousand Oaks, CA: SAGE Publications, Inc. (pp. 77-83)

[3] Crossman, A. (2014). Poverty. Available: http://sociology.about.com/od/P_Index/g/Poverty.htm Retrived: August 25, 2015

[4] Diaz, A. (2018). DSWD sums up 4Ps gains in Northern Samar, Philippine Information Agency 8- Northern Samar

[5] Dela Torre, B. (2016). Financing Education through the Pantawid Pamilyang Pilipino Program (4Ps)

[6] Doll,Eslami, \& Walters, 2013. Understanding Why students Drop Out of High School, According to Their Own reports: Are They Pushed or Pulled, or Do They Fall Out? A Comparative Analysis of Seven Nationally Representative Studies.

[7] Heigham, J. et al. (2009). Qualitative Research in Applied Linguistics A Practical Introduction; Palgrave Macmillan

[8] Jordan, W. J.; Lara Julia; McPartland, J. M. (1996) -„Exploring the causes of early dropout among race -ethnic and gender groups" IN Youth \& Society 28(1): 6-94

[9] Junio, L. (2014). Philippine News Agency

[10] Fernandez, L. \& Olfindo, R. (2011). Overview of the Philippines' conditional cash transfer program: The Pantawid Pamilyang Pilipino Program (Pantawid Pamilya). Washington DC. World Bank.

[11] Montella, M., Delavin, E.,Villanueva ,R., \& Turco, R.(2015) Pantawid Pamilyang Pilipino Program (4Ps): Assistance to Pupil's Education

[12] Rumberger, R. W. (2011). Dropping out: Why students drop out of high school and what can be done about it. Cambridge, Mass.: Harvard University Press.

[13] Sampson, R.J., Morenoff, J.D., \& Gannon-Rowley, T. (2002). Assessing "neighborhood effects": Social processes and new directions in research. Annual Review of Sociology, 28, 443-478.

[14] Stearns Elizabeth, Glennie Elizabeth J. (2006) -„When and Why Dropouts Leave High School” IN Youth \& Society Volume 38 Number 1 September, 29-57

[15] Velarde, R. \& Fernandez, L. (2011). Philippines- welfare and distributional impacts of the pantawid pamilyang pilipino $\quad$ program. Available: http: wds.worldbank.org/servlet/WDSeContentServes/WDSP/IB/2012//06/11/000426104/Rendered/PDF/69 4230BRIOP1180ang0Program.pdfRetrieved: May 24,2019

[16] https://www.academia.edu/35431416/THE_HARDSHIPS_AND_BENEFITS_OF_4PS_STUDENTBENEFICIARIES Retrived: August 25, 2019

[17] Philippine Institute for Philippine Studies, https://www.pids.gov.ph/press-releases/328 